\title{
Genetic analysis of salicylic acid-mediated defenses responses and histopathology in the huanglongbing pathosystem
}

\author{
Tiago Silva Oliveira ${ }^{1,2}$, Laís Moreira Granato을 Diogo Manzano Galdeano ${ }^{1}$, \\ João Paulo Rodrigues Marques ${ }^{3}$, Luciane Fender Coerini ${ }^{1,3}$, Juliana Freitas-Astúa ${ }^{4} \&$ \\ Marcos Antonio Machado ${ }^{1}$
}

\section{SUMMARY}

The emergence of citrus huanglongbing (HLB) has been a constraint for worldwide citrus growers. HLB disease is associated to species of the biothrophic bacteria Candidatus Liberibacter spp. (CaL). In this study, we assessed the transcriptional status of salicylic acid (SA) genes and associated defenses between two contrasting citrus genotypes during challenge with $\mathrm{Ca}$. Liberibacter asiaticus or $\mathrm{Ca}$. Liberibacter americanus. Citrus sinensis exhibited the most evident alterations in gene expression of evaluated genes, when compared with Poncirus trifoliata. Upstream pathway SA genes showed a slight upward regulation in $C$. sinensis. Salicylic acid biosynthesis and accumulation might be impaired as we observed a low expression level of SA biosynthesis related genes. Moreover, genes associated to SA metabolism showed a slight induction. These results may account for the absence of significant downstream defense response related to salicylic acid. Leaf anatomical analysis revealed callose accumulation in both HLB infected, $C$. sinensis and $P$. trifoliata sieve tube elements (STE), although only $C$. sinensis exhibited collapsed STE. Our data corroborate other studies and suggest that the SA biosynthesis and metabolism related genes might be involved in the contrasting response to $\mathrm{CaL}$ in different citrus genotypes. Additionally, we suggest that collapsed STE might have a prominent implication in symptomatology of highly susceptible plants.

Index terms: SAR, plant-pathogen interaction, gene expression, callose deposition.

\section{Análises genéticas das respostas de defesas mediadas por ácido salicílico e histopatologia no patossistema huanglongbing}

\section{RESUMO}

A ocorrência do huanglongbing (HLB) dos citros tem sido um sério problema para os citricultores em todo o mundo. O HLB está associado a bactérias biotróficas da espécie Candidatus Liberibacter spp. (CaL). Nesse estudo, nós avaliamos o perfil transcricional dos genes da via do ácido salicílico (SA) e genes associados a defesa em dois genótipos contrastantes após desafio com $\mathrm{Ca}$. Liberibacter asiaticus ou $\mathrm{Ca}$. Liberibacter americanus. Citrus sinensis exibiu maiores alterações na expressão gênica dos genes avaliados, quando comparado com Poncirus trifoliata. Genes upstream da via do

\footnotetext{
${ }^{1}$ Centro de Citricultura Sylvio Moreira, Instituto Agronômico de Campinas, Cordeirópolis, SP, Brasil

${ }^{2}$ Universidade Estadual de Campinas - UNICAMP, Campinas, SP, Brasil

${ }^{3}$ Escola Superior de Agricultura "Luiz de Queiroz", Universidade de São Paulo - USP, Piracicaba, SP, Brasil

${ }^{4}$ Embrapa Mandioca e Fruticultura, Cruz das Almas, BA, Brasil

Corresponding author: Laís Moreira Granato, Centro de Citricultura Sylvio Moreira, Instituto Agronômico de Campinas, Rodovia Anhanguera, Km 158, CEP 13490970, Cordeirópolis, SP, Brasil. E-mail: laisgranato@gmail.com
} 
SA demonstraram aumento da expressão em C. sinensis. A biossíntese e acumulação do ácido salicílico deve ter sido prejudicada, uma vez que foi observado uma baixa expressão relativa dos genes relacionados a biossíntese do SA. Além disso, os genes associados ao metabolismo do SA tiveram uma leve indução da expressão. Esses resultados podem explicar a ausência de significância nos valores de expressão gênica dos genes downstream da via do SA, os quais são relacionados às respostas de defesa da planta. Análises anatômicas das folhas revelaram um acúmulo de calose nos elementos de tubo crivado (STE), tanto em C. sinensis quanto em $P$. trifoliata infectados. Nossos dados corroboram outros estudos e sugerem que os genes relacionados a biossíntese e metabolismo do SA podem estar envolvidos na resposta de genótipos de Citrus contrastantes à infecção por CaL. Além do mais, nós sugerimos que STE colapsados podem ter uma implicação importante na sintomatologia de plantas altamente suscetíveis.

Termos de indexação: SAR, interação planta-patógeno, expressão gênica, deposição de calose.

\section{INTRODUCTION}

Huanglongbing (HLB) is a systemic citrus disease associated with the bacteria Candidatus Liberibacter (CaL) (Wang et al., 2017; Wang \& Trivedi, 2013). Ca. L. asiaticus (CLas) and $\mathrm{Ca}$. L. americanus (CLam) are found in Brazil (Teixeira et al., 2005; Coletta-Filho et al., 2004) and the disease has caused significant economic impact to citrus growers (Bassanezi et al., 2011). Citrus typical symptoms are blotchy mottle; yellowed veins, leaves and shoots; root system decline; off-season flowering; small and lopsided fruits and dark aborted seeds (Gottwald, 2010; Bové, 2006). All of these symptoms occur because of multiple factors, including the callose accumulation in phloem sieve tube elements (STE) (Boava et al., 2017; Koh et al., 2012; Graça et al., 2016).

Callose deposition around the site of infection is considered a defense mechanism against pathogen colonization in host plants (Luna et al., 2011). In the HLB pathosystem, it has been considered the predominant factor associated with phloem plugging in CLas infected citrus, contributing to the progress of the disease (Wang et al., 2017; Koh et al., 2012). Callose may negatively regulate salicylic acid (SA) mediated defenses; on the other hand, the hormone SA may induce callose accumulation (Ellinger \& Voigt, 2014; Nishimura, 2008). SA acts as a key regulator of plant defenses against a broad-spectrum group of pathogens (Tanaka et al., 2015). The increase of reactive species of oxygen (ROS) during the pathogen attack stimulates the SA biosynthesis and signaling (Pitino et al., 2017; Xing et al., 2013). Although SA and ROS levels increase systemically, sometimes they are not high enough to lead to a massive programmed cell death, so expression of defense related genes is activated instead (Kawano \& Bouteau, 2013). This response is known as Systemic Acquired Resistance (SAR), an induced response that promotes resistance primarily against biotrophic pathogens (Ádám et al., 2018).

Several studies on citrus $\mathrm{x} \mathrm{CaL}$ interaction have been done in pursuit of strategies to control the disease. However, HLB remains a challenge to citrus breeders and growers. We assessed the transcriptional profiles of SA-related SAR genes and performed a histopathological analysis of C. sinensis and P. trifoliata plants manifesting contrasting symptoms during infection, to better understand the plant response in this pathosystem.

\section{MATERIALS AND METHODS}

\section{Plant material and experimental set up}

Poncirus trifoliata (L.) Raf. plants were used as HLB tolerant/resistant genotype and Citrus sinensis (L.) Osbeck var. Hamlin as susceptible. For bacterial inoculation, plants were grafted with buds obtained from infected citrus plants. Non-grafted $P$. trifoliata and $C$. sinensis were used as control samples. Plants were maintained in greenhouse at $25 \pm 3^{\circ} \mathrm{C}$ under natural photoperiod. Two independent experiments were carried out using CLam or CLas. For gene expression analyses, time-course experiments of early [4 weeks after inoculation (wai)] and late stage of infection were performed. Late stage of infection was established as the moment when the inoculated plants exhibited typical HLB symptoms and ranged from 40 wai for CLas to 110 wai to CLam infected plants (Figure 1). Mature leaf samples were collected randomly, frozen into liquid nitrogen, grinded to a fine powder and kept at $-80^{\circ} \mathrm{C}$. 


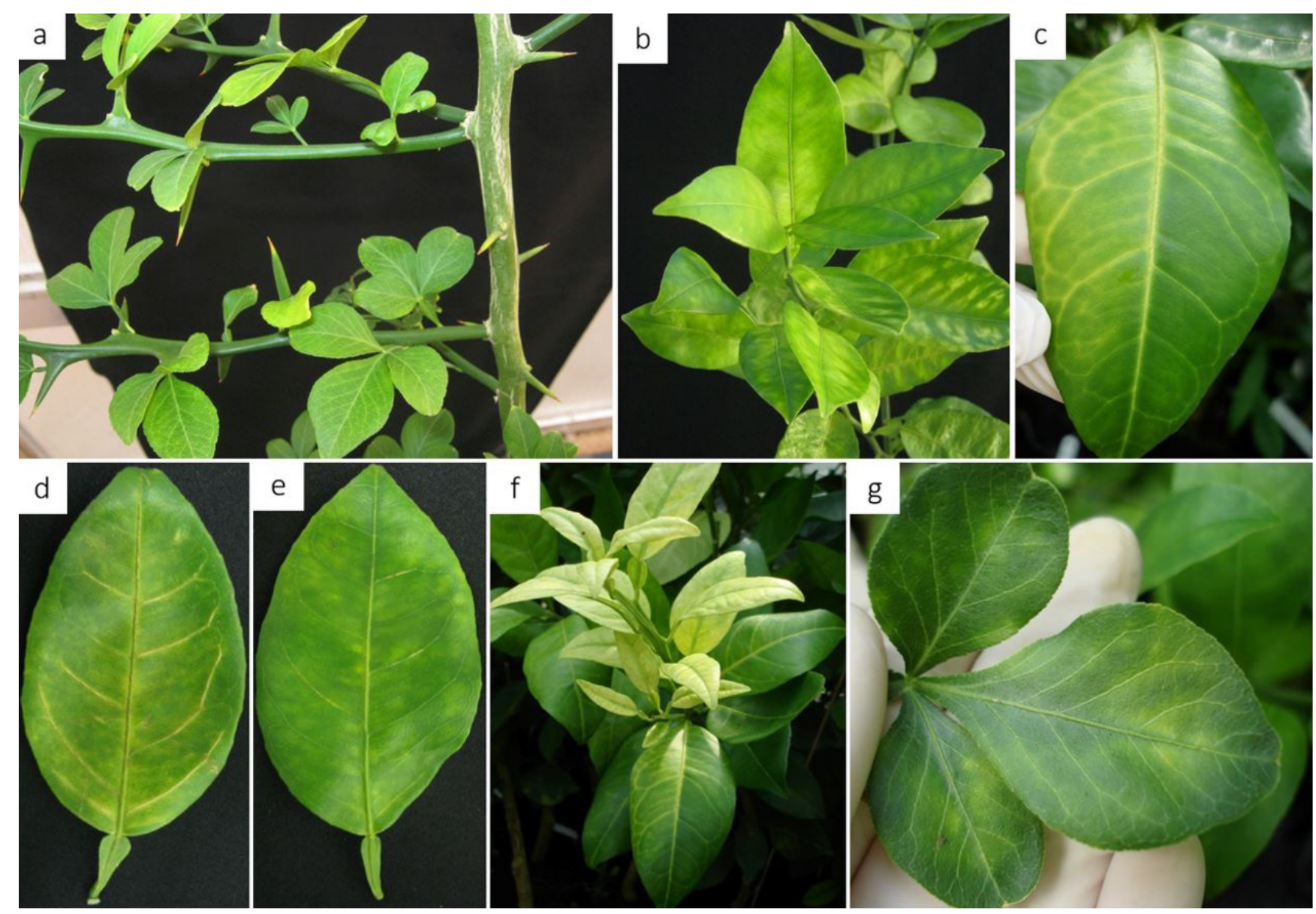

Figure 1. Plants of Citrus sinensis (b-f) and Poncirus trifoliata (a and g) inoculated with CLas (a, b, d, e) and CLam (c, f, g). Blotchy mottle leaves and shoots (b); leaves with veins corks and yellow sectors (d, e); yellowed veins (c, d); leaves without defined symptoms $(a, g)$.

\section{RNA isolation, cDNA synthesis and gene expression analysis}

Total leaves RNA from CLas and CLam positive and healthy plants were extracted using the RNeasy Plant mini Kit (QIAGEN, Valencia, CA, USA), according to the manufacturer's instruction. DNase I (QIAGEN) treatment was applied to degrade genomic DNA contaminants in RNA samples. The RNA concentration was determined by measuring the absorbance at $260 \mathrm{~nm}$ (A260) in a NanoDrop 8000 spectrophotometer (Thermo Fisher Scientific Inc., Wilmington, DE, USA), and RNA integrity assessed by electrophoresis on $1.2 \%$ denaturing agarose gel. The ratio of OD at 260 and $280 \mathrm{~nm}$ was used to estimate the RNA purity. cDNA synthesis was carried using RevertAid H Minus First Strand cDNA Synthesis Kit (Fermentas, Burlington, ON, Canada), from $1 \mu \mathrm{g}$ of RNA and oligo(dT) primers, in a $20 \mu \mathrm{L}$ reaction volume.
For gene expression analysis, aliquots $(3 \mu \mathrm{L})$ of 50 -fold diluted cDNA samples were used as template in a $25 \mu \mathrm{L}$ reaction containing $1 \mathrm{X}$ Fast SYBR Green PCR master mix (Applied Biosystems, Foster City, CA, USA) and $200 \mathrm{nM}$ of each specific primer. The reactions were carried out in an ABI PRISM 7500 FAST sequence detection system (Applied Biosystems) with a program of $95^{\circ} \mathrm{C}$ for 20 seconds followed by 40 cycles of $95^{\circ} \mathrm{C}$ for 03 seconds and $60^{\circ} \mathrm{C}$ for 30 seconds.

\section{Selection of salicylic acid-related SAR genes}

Arabidopsis thaliana genes related to SA pathway were obtained on TAIR (Berardini et al., 2015) and used for a search of citrus orthologous genes by BLASTX on Phytozome (Goodstein et al., 2012). All these analyses were performed using BLAST default parameters. Real-time 
quantitative PCR (qPCR) primers were designed using Primer3Plus software tool (Untergasser et al., 2007). For those genes belonging to gene families, qPCR primers were carefully obtained by observing an alignment of coding sequences and checking a unique annealing site between them.

The genes analyzed were grouped in categories according to their role along the SA pathway: 1) upstream pathway signaling; 2) SA biosynthesis and metabolism;
3) downstream pathway signaling. An Applied Biosystems 3730 capillary DNA sequencer (Applied Biosystems) was used to obtain the amplicon sequences, which were evaluated by aligning to the coding target sequence. Primers specificity was also verified by $2 \%(\mathrm{w} / \mathrm{v})$ agarose gel electrophoresis of the PCR products and by qPCR melting curves. The description of the selected genes and primers sequences are summarized in Table 1.

Table 1. Citrus genes identification of salicylic acid (SA) pathway signaling. The analyzed genes were grouped in categories according to their role throughout salicylic acid pathway: upstream pathway signaling, SA biosynthesis and metabolism and downstream pathway signaling

\begin{tabular}{|c|c|c|c|c|}
\hline AtID & PhytozomeID & Gene & Gene description & Primers (5'-3') \\
\hline \multicolumn{5}{|c|}{ Upstream pathway signaling genes } \\
\hline \multirow[t]{2}{*}{ AT3G48090 } & orange1.1g007278m & EDS1 & Component of $\mathrm{R}$ & F TTTACAGGGCATTCCTCAGCTGGT \\
\hline & & & $\begin{array}{l}\text { gene-mediated } \\
\text { disease resistance }\end{array}$ & R TATAGGTGGCATTCTGCTGGTGCT \\
\hline \multirow[t]{2}{*}{ AT3G52430 } & orange1.1g007061m & PAD4 & Encodes a & F GCTTGGCAAATTCTGGGATGGTGT \\
\hline & & & $\begin{array}{l}\text { lipase-like protein } \\
\text { that are important } \\
\text { for SA-mediated } \\
\text { defenses }\end{array}$ & R ACCTCCTTGGTCTTCCATGCTTCA \\
\hline \multirow[t]{2}{*}{ AT4G11260 } & orange1.1g017264m & HSP90 & Heat shock protein & F GCAAGCCATTGAGATTAGCC \\
\hline & & & & R GCCACCTTAGCCGTTTCATA \\
\hline \multirow[t]{2}{*}{ AT5G51700 } & orange1.1g027086m & RAR1 & Required for mla12 & F GCTCCTGCTCCTTCAACAAC \\
\hline & & & resistance & R CTGGGGCATAATTGGTCTGT \\
\hline \multirow[t]{2}{*}{ AT5G06320 } & orange1.1g027210m & NDR1 & Non-race specific & F TTGTAACGCATGGGCTGAAACAG \\
\hline & & & $\begin{array}{l}\text { disease resistance } \\
\text { gene }\end{array}$ & R TGGTGCAGGTCCTCAATCTTTGGA \\
\hline \multirow[t]{2}{*}{ AT1G73805 } & orange1.1g011961m & SARD1 & Key regulator for & F GCCGAAGGAGTTTTGAATGA \\
\hline & & & $\begin{array}{l}\text { ICS1 induction and } \\
\text { SA synthesis }\end{array}$ & R AATTTGCCAATCGTTGCTTC \\
\hline & SA b & osynthesi & and metabolism rels & ted genes \\
\hline \multirow[t]{2}{*}{ AT1G74710 } & orange1.1g008131m & ICS1 & Isochorismate & F TGCTCGATTGGCGGGCAGAC \\
\hline & & & synthase & R AGGCGTGCCTCTTCAGTCGGA \\
\hline \multirow[t]{2}{*}{ AT3G53260 } & orange1.1g005031m & PAL2 & Phenylalanine & F GGCTGCCATTGCCACGTCCT \\
\hline & & & ammonia lyase & R AGAGCACCGCCGTTCTTGGT \\
\hline \multirow[t]{2}{*}{ AT5G04230 } & orange1.1g004955m & PAL3 & Phenylalanine & F AACTGGACCGTGGCAGCGGA \\
\hline & & & ammonia lyase & R GACTCGCCGCCGAGCTTCAC \\
\hline \multirow[t]{2}{*}{ AT3G10340 } & orange1.1g037382m & PAL4 & Phenylalanine & F TCACCGGCCGGCCCAATTCT \\
\hline & & & ammonia lyase & R GCGAGACCCTCCTTAGGCTGC \\
\hline \multirow[t]{2}{*}{-} & orange1.1g016039m & PAL5 & Phenylalanine & F CTGACGATGGGGGTCAATGGGGA \\
\hline & & & ammonia lyase & R CGCTGCAGGGATCATCAGCGTA \\
\hline \multirow[t]{2}{*}{ AT2G43820 } & orange1.1g012194m & SAGT1 & Salicylic acid & F CCAAGCGCCTAGATCACAA \\
\hline & & & glucosyltransferase & R GGACGAGGATGACGAATCTC \\
\hline \multirow[t]{3}{*}{ AT3G11480 } & orange1.1g017514m & BSMT1 & Benzoic acid/ & F GTTTAACGAGGCCGTTGATG \\
\hline & & & SA carboxyl & R TCGTCAAGGAAACTGTCACG \\
\hline & & & Methyltransferase & \\
\hline
\end{tabular}


Table 1. Continued...

\begin{tabular}{|c|c|c|c|c|}
\hline AtID & PhytozomeID & Gene & Gene description & Primers (5'-3') \\
\hline \multicolumn{5}{|c|}{ Downstream pathway signaling genes } \\
\hline \multirow[t]{2}{*}{ AT1G64280 } & orange1.1g007923m & NPR1 & Nonexpresser of PR & F AAGGGAGCTCGGCCATCAGA \\
\hline & & & genes 1 & R TGCAGCCTTAGTGAGCCGCT \\
\hline \multirow[t]{2}{*}{ AT5G45110 } & orange1.1g007849m & NPR3 & Regulate defense & F TCTGGAGGGAGAAATGAGG \\
\hline & & & $\begin{array}{l}\text { responses against } \\
\text { bacterial pathogens }\end{array}$ & R TGTGGGAGGTGATAAAGGC \\
\hline \multirow[t]{2}{*}{ AT3G56400 } & orange1.1g021598m & WRKY70 & WRKY70 & F CAGCAGCAGCAGGCGAATTCTT \\
\hline & & & transcription factor & R GTCCTTCGCCGCCGGTCTCT \\
\hline \multirow[t]{2}{*}{ AT4G03550 } & orange1.1g000259m & GSL5 & Callose synthase & F CCCAAGTATTCCGGCCCTTT \\
\hline & & & & R CACGGGGGTCAAGACAATCA \\
\hline \multirow[t]{2}{*}{ AT4G04970 } & orange1.1g000258m & GSL1 & Callose synthase & F CAGGTGTATGGGCAGCAGAA \\
\hline & & & & R CATCCCTCCCCAAGTGAACC \\
\hline
\end{tabular}

\section{Data analysis}

Efficiency of qPCR amplification and cycle threshold $(\mathrm{Ct})$ were obtained using the Miner web-based tool from raw data of the kinetics of individual qPCR assay, according to Zhao \& Fernald (2005). The relative quantification of gene expression level was calculated using the GenEx v2.6.4 software (MultiD analysis, Exiqon) and three biological and technical replicates were used for all conditions. We considered a $\leq 0.05 p$-value for significant gene expression of \pm 1 - fold change, in a two-tailed t-test. The housekeeping genes TIP41 and SAND were used as reference genes based on previous selection according to Mafra et al. (2012).

\section{Microscopical analyses}

For general anatomical analyses, petiole samples from CLas infected $P$. trifoliata and $C$. sinensis were collected and immediately fixed in Karnovsky solution (Karnovsky, 1965). Samples were submitted to a vacuum pump to remove the air in the intercellular spaces. After fixation, they were dehydrated in a graded series of ethyl alcohol and embedded in Leica Historesin ${ }^{\circledR}$ (Heraeus Kulzer, Hanau, Germany) media. Cross and longitudinal sections of 7-5 $\mu \mathrm{m}$ thick were cut with a rotatory microtome and stained with toluidine blue (Sakai, 1973) and the samples were mounted using synthetic resin Entelan ${ }^{\circledR}$.

To study callose deposition, petioles were harvested, rapidly fixed in cold FAA fixative (95\% ethanol, 37\% formaldehyde, glacial acetic acid, deionized water, in the proportions of 10:2:1:7) and submitted to vacuum pump for 15 minutes. Longitudinal sections were made on sliding microtome (Leica MS 2000R), stained with $1 \%$ aniline blue (diluted in alcohol $70 \%$ ) for $10 \mathrm{~min}$ and examined using a Filter A4 (excitation 340-380 nm, emission 450-490 nm) under Leica DMLB epifluorescence microscopy (Leica ${ }^{\mathrm{TM}}$ - Wetzlar, Germany) All digital images were acquired with a digital camera system with IM50 (Leica ${ }^{\mathrm{TM}}$ - Wetzlar, Germany) software.

\section{RESULTS AND DISCUSSION}

Here we provide an overview of the transcriptional profile for key SA-related SAR genes in contrasting genotypes upon $\mathrm{Ca}$. Liberibacter spp. infection. To evaluate the dynamics of gene expression, the presence of both bacteria was confirmed in the infected plants (data not shown) and total RNA was isolated from leaf tissues collected in early (4 wai) and late (symptomatic) stages of infection, besides from healthy plants (non-inoculated). CLas-infected P. trifoliata plants lacked clear symptoms (Figure 1a); in contrast, CLas infected C. sinensis plants exhibited typical symptoms 40 wai (Figure 1b, c, d, e), in agreement with the literature (Folimonova et al., 2009). As for CLam-infected C. sinensis, typical disease symptoms appeared around 110 wai (Figure 1f), while CLam infected $P$. trifoliata also remained asymptomatic (Figure 1g).

In general, when comparing inoculated and non-inoculated plants, the most significant difference in expression was observed to SA biosynthesis and metabolism associated genes (Table 2; Figure 2). Almost all SA biosynthesis related genes showed a downward trend in expression, including 
Table 2. Comparison of the expression levels of salicylic acid pathway-related SAR genes in Poncirus trifoliata and Citrus sinensis upon Candidatus Liberibacter americanus (CLam) or Ca. Liberibacter asiaticus (CLas) infection. The analyses were performed in early (ES) and late stages (LS) of infection. The analyzed genes were grouped in categories according to their role throughout salicylic acid pathway: upstream pathway signaling, SA biosynthesis and metabolism, and downstream pathway signaling

\begin{tabular}{|c|c|c|c|c|c|c|c|c|}
\hline \multirow{3}{*}{ Genes } & \multicolumn{2}{|c|}{ Trifoliata/CLam } & \multicolumn{2}{|c|}{ Trifoliata/CLas } & \multicolumn{2}{|c|}{ Citrus/CLam } & \multicolumn{2}{|c|}{ Citrus/CLas } \\
\hline & \multicolumn{8}{|c|}{ Upstream pathway signaling genes } \\
\hline & ES & LS & ES & LS & ES & LS & ES & LS \\
\hline EDS1 & -0.11 & -0.20 & -0.37 & 0.22 & -0.63 & 0.90 & 0.13 & $2.64^{*}$ \\
\hline PAD4 & -0.42 & -0.29 & 0.98 & 0.66 & -0.75 & $1.65^{*}$ & -0.61 & $1.72 *$ \\
\hline HSP90 & -0.73 & 0.67 & $-1.95 *$ & 1.59 & -1.20 & -1.60 & -0.78 & 0.18 \\
\hline RAR1 & 0.30 & 0.61 & 0.36 & 0.44 & 0.10 & -0.44 & -1.10 & 0.33 \\
\hline NDR1 & 0.33 & $1.6^{*}$ & -0.14 & 0.84 & 0.11 & $1.4^{*}$ & -0.31 & $4.4^{*}$ \\
\hline \multirow[t]{3}{*}{ SARD1 } & 1.03 & $4.0 *$ & 0.74 & 0.76 & 0.17 & 0.62 & 0.04 & -0.29 \\
\hline & \multicolumn{8}{|c|}{ SA biosynthesis and metabolism related genes } \\
\hline & ES & LS & ES & LS & ES & LS & ES & LS \\
\hline ICS1 & $-0.66^{*}$ & $-2.07 *$ & 0.31 & $-4.88 *$ & 1.24 & $-0.13 *$ & -0.02 & -0.33 \\
\hline PAL2 & $4.03 *$ & -2.20 & 0.17 & 2.02 & -0.41 & $-1.76^{*}$ & -0.09 & $-2.42 *$ \\
\hline PAL3 & $2.44 *$ & 0.23 & 0.38 & 1.64 & $-1.88^{*}$ & -0.83 & -0.55 & -2.56 \\
\hline PAL4 & $1.3^{*}$ & -0.94 & 0.16 & 2.54 & 0.42 & $-1.97 *$ & 0.14 & -2.69 \\
\hline PAL5 & 1.85 & -1.51 & 1.07 & 3.14 & 3.44 & $-2.22 *$ & 0.48 & -5.62 \\
\hline SAGT1 & $-1.0^{*}$ & 0.47 & -0.32 & 0.87 & -0.56 & $1.90 *$ & -0.33 & 1.30 \\
\hline \multirow[t]{3}{*}{ BSMT1 } & -0.26 & 0.8 & -0.93 & 0.48 & -0.22 & $2.65 *$ & -2.62 & $3.71 *$ \\
\hline & \multicolumn{8}{|c|}{ Downstream pathway signaling genes } \\
\hline & ES & LS & ES & LS & ES & LS & ES & LS \\
\hline NPR1 & 0.08 & -0.33 & -0.23 & $-1.2 *$ & -0.15 & $-0.09 *$ & 0.08 & -0.03 \\
\hline NPR3 & $2.86^{*}$ & -0.50 & 0.26 & 0.08 & 0.16 & 0.92 & -0.27 & $-1.18^{*}$ \\
\hline WRKY70 & $-0.44^{*}$ & 0.33 & -0.31 & 1.64 & 0.55 & 0.27 & -0.11 & 0.10 \\
\hline GSL5 & -1.06 & -0.47 & 0.03 & -0.10 & 1.78 & $-1.67 *$ & -0.26 & $0.37 *$ \\
\hline GSL1 & 0.58 & -0.07 & -1.16 & 0.02 & 1.16 & $-1.93 *$ & -0.13 & 0.23 \\
\hline
\end{tabular}

The differentially gene expression analyses were based on the fold ratio $\geq 1$ or $\leq-1$ between infected and non-infected plants. Genes with a $p$-value $\leq 0.05$ were considered significant and are present with asterisk.

ICS1 (ISOCHORISMATE SYNTHASE1) (Table 2, Figure 2). The isochorismate pathway produces $90 \%$ of plant SA (Wildermuth et al., 2001), while PAL (PHENYLALANINE AMMONIA-LYASE) pathway is responsible for the remaining SA production (Chen et al., 2009). PAL gene family also showed decrease of expression in late stages of infection, even though trifoliata exhibited increase of expression in early stage of infection (Figure 2). Slisz et al. (2012) showed phenylalanine accumulation on symptomatic citrus fruits infected with CLas, which could be due to inhibition of the phenylpropanoid biosynthetic pathway by the bacteria. Phenylpropanoids are induced in response to biotic and abiotic stresses and the initial step in the phenylpropanoid biosynthetic pathway is the conversion of phenylalanine to cinnamic acid by the action of PAL
(Chen et al., 2009). Downregulation of SA biosynthesis genes can be explained by two hypotheses: SA level in both stages evaluated in this work is high, thus the expression of ICS1 and PAL genes is low because SA synthesis is no more necessary or ICS1 is potentially targeted by CaL. to suppress SA-mediated plant immunity, as showed to other plant pathogens (Qi et al., 2018).

For SA metabolism, BSMTI (BENZOIC ACID/SALICYLIC ACID CARBOXYL METHYLTRANSFERASE1) - a SA metabolic enzyme gene - had significant level of induction in late stage of infection of both CLas and CLam (Figure 2). This gene encodes a SABATH methyltransferase that catalyzes the methylation of SA into methylsalicylate (MeSA) and benzoic acid (a SA precursor) into methylbenzoate (MeBA) (Chen et al., 

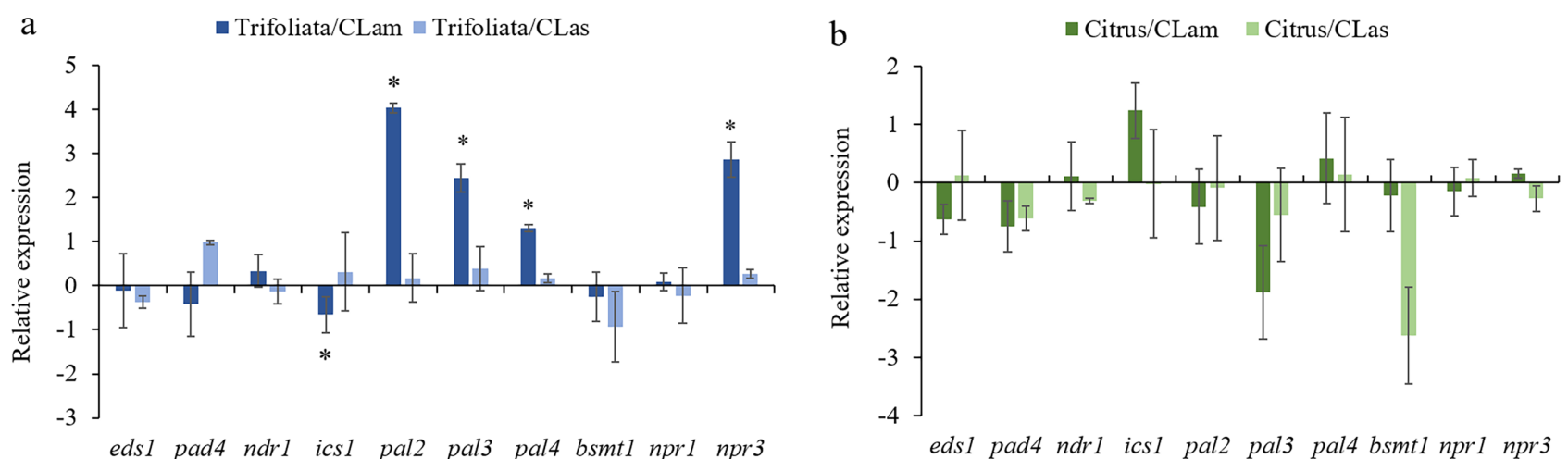

Early stages
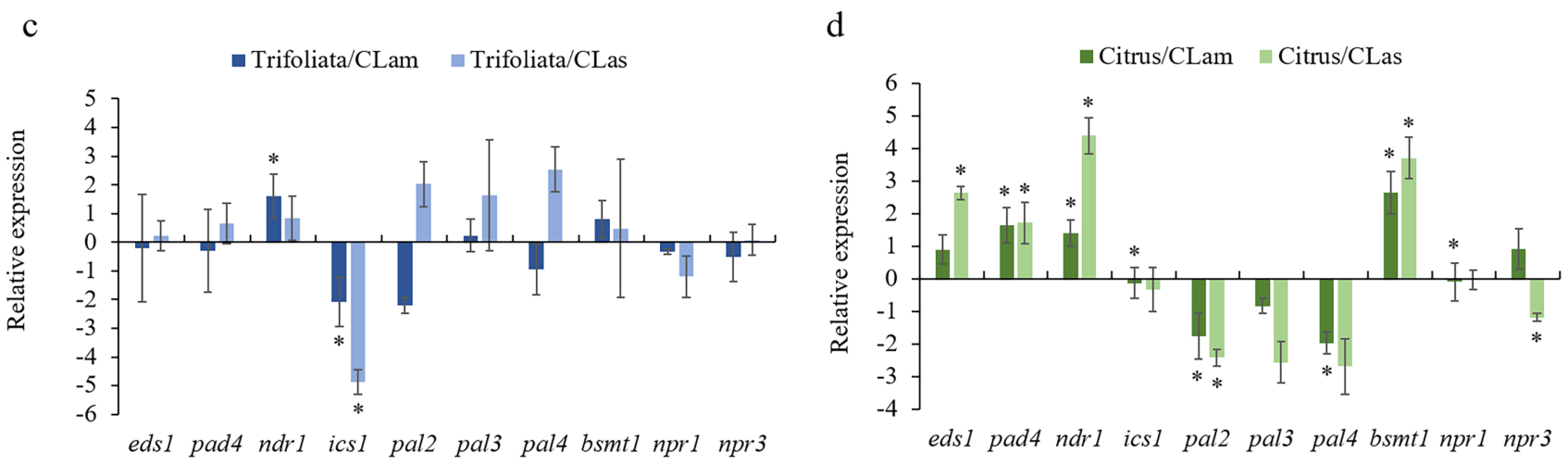

Late stages

Figure 2. Relative expression of upstream SA pathway signaling genes and SA metabolism related genes in Poncirus trifoliata and Citrus sinensis upon Candidatus Liberibacter americanus (CLam) or Ca. Liberibacter asiaticus (CLas) infection. a. Graphic of relative expression of $P$. trifoliata in early stages of CLam and CLas infection. b. Graphic of relative expression of $C$. sinensis in early stages of CLam and CLas infection. c. Graphic of relative expression of $P$. trifoliata in late stages of CLam and CLas infection. d. Graphic of relative expression of $C$. sinensis in late stages of CLam and CLas infection. Genes with $p$-value $\leq 0.05$ were considered significant and are present with asterisk.

2003). BSMT1 mutants showed compromised SAR signaling, suggesting MeSA as a critical phloem-mobile SAR signal (Koo et al., 2007; Liu et al., 2010). However, MeSA seems not to be the only molecule essential to establish SAR (Attaran et al., 2009; Zheng et al., 2012; Maruri-López et al., 2019), and several candidate molecules have been suggested (Shah \& Zeier, 2013). Moreover, some pathogens manipulate phytohormone pathways, converting SA to inactive derivatives as MeSA, to bypass defenses responses (Cui et al., 2005; Qi et al., 2018). In A. thaliana, Pseudomonas syringae prevents the SA accumulation by inducing the SA metabolic gene BSMT1 and repressing SA synthesis gene ICS1, similar to what was observed in late stages of CLam inoculated-citrus plants (Table 2). Therefore, SA is converted to the volatile form (MeSA) and defenses against the pathogen are suppressed
(Zheng et al., 2012). Interestingly, it has been shown that MeSA and other specific compounds are released by CLas-infected plants, which may render to citrus CLas hosts more attractiveness to the vector Diaphorina citri than non-infected plants (Mann et al., 2012). MeSA acts as an olfactory signal to D. citri (Grafton-Cardwell et al., 2013), but once the insects settle on infected leaves and possibly acquire the bacteria, they soon move to a healthy plant (Mann et al., 2012).

For upstream pathway signaling genes, EDS1 (ENHANCED DISEASE SUSCEPTIBILITY1) and NDR1/HIN1-like (NHL) were the most up regulated in citrus after CLas infection (late stage) (Table 2; Figure 2). EDS1 is an important regulator of SA-dependent defense response against biotic stress, for example, involved in hypersensitive response (HR), accumulation of 
SA and SA-dependent signaling (Shah \& Zeier, 2013; Rietz, et al.2011). NDR1/HIN1-like is a plasma membrane protein, member of a gene family involved in multiple roles in cell physiology (Knepper et al., 2011). Previous studies have identified increase in expression of NDRI/ HIN1-like related genes during CLas or CLam infection in C. sinensis (Lu et al., 2013; Mafra et al., 2013). Vilaine et al. (2013) showed that arabidopsis overexpressing NHL26 accumulated high levels of carbohydrate in phloem tissue of mature leaves, higher shoot biomass, contrasting with slower root growth and a lower seed yield. HLB infected citrus species manifest similar characteristics, which have been considered a consequence of phloem blockage (Johnson et al., 2014; Wang \& Trivedi, 2013). Besides that, PAD4 (PHYTOALEXIN DEFICIENT4) is a lipase-like protein which showed a slight up regulation in CLas infected citrus in the late stage of infection (Table 2). Overexpression of EDS1 and PAD4 activates the expression of both SA-dependent and SA-independent genes. Both the SA dependent and SA-independent functions of EDS1 and PAD4 contribute to plant basal immunity and effector-triggered immunity (ETI) (Rietz et al., 2011; Cui et al., 2017). These genes were also significantly induced in other recent transcriptional studies on HLB pathosystem (Fan et al., 2011; Mafra et al., 2013; Rawat et al., 2015).

Regarding downstream SA pathway genes, few significant alterations were observed, and most of the genes exhibited a down regulation expression (Table 2). NPR1 has been described as receptor of SA (Wu et al., 2012) and it was downregulated in this study (Table 2). NPR1 activity is regulated by proteasome mediated degradation, which is carried out by the NPR1 paralogues, NPR3 and NPR4. When SA levels are low, NPR4 maintain low NPR1 levels, but when SA levels increase, NPR4-NPR1 interaction is disrupted, leading the accumulation of NPR1. Furthermore, when SA level is extremely high, NPR3 binds NPR1 leading to NPR1 degradation (Spoel et al., 2009; Dempsey $\&$ Klessig, 2017). NPR1 turnover ensures a correct defense activation and the establishment of SA-induced responses (Spoel et al., 2009). NPR3 and NPR4 might be involved also in transcriptional regulation of SA-induced defense genes (Maruri-López et al., 2019). So, the level of NPR1 in the evaluated stages of CaL. infection is agreeing with high SA. Previous results has already showed down regulation of defense-related proteins in CLas-infected C. lemon (Nwugo et al., 2013), PR genes in CLas-infected sweet orange and rough lemon (C. jambhiri) (Fan et al.,
2012), and NBS-LRR defense-related genes in sweet orange (Aritua et al., 2013).

Even with some minor differences in the gene expression profiles, it was not possible to establish a correlation between symptom development and systemic alteration in expression of SAR-related SA genes. Moreover, $P$. trifoliata plants exhibited even lower alteration in their gene expression profile. Therefore, regardless the noticeable fact that many important downstream pathway SA-genes are not active in diseased plants, it is not possible to assert the direct involvement of SA in citrus defense or susceptibility against HLB. SA-mediated defense seems not to be infallible because CaL. possibly have ways to overcome plant defense mechanism, as to direct lower SA accumulation by converting SA to inactive derivatives as MeSA, to interrupt SA biosynthesis by targeting specific pathways and to interfere with SA signaling (Qi et al. 2018). Li et al. (2017) showed that CLas may suppress plant defense by employing an active salicylate hydroxylase, thus halting SA accumulation and HR and allowing the pathogen to overcome the host defense.

Studies have shown that citrus plants display several physiological and cytological alterations in the phloem, including callose accumulation in response to CLas infection and hyperplasia in phloem parenchyma (Achor et al., 2010; Etxeberria et al., 2009; Pitino et al., 2016). In this study, we compared callose deposition and phloem alterations between healthy and CLas infected $C$. sinensis and $P$. trifoliata. Infected $C$. sinensis showed hypertrophy of the phloem parenchyma cells, promoting internal pressure in this tissue and leading to the collapse of the sieve tube elements (STE) (Figure 3a-b, 3d-e). Collapsed STE were not observed in P. trifoliata HLB infected (Figure 3j-k). Non-infected $C$. sinensis displayed few small and isolated fluorescent spots related to callose deposition (Figure 3c), whereas infected plants showed large callose deposits in several STE (Figure 3f). Koh et al. (2012) also observed similar levels of callose deposits in CLas symptomatic and asymptomatic leaves causing constriction, but not completely occlusion of sieve pores in infected STE. Base on the STE anatomy it was possible to recognize two different types of sieve plates: $C$. sinensis has simple sieve plates (Figure 3c) and P. trifoliata presents compound sieve plates (Figure 3i). This anatomical data could represent an important feature to minimize the effect of the phloem transportation caused by callose deposition in infected plants. Further ultrastructural analysis needs to be conducted to evaluate whether or not the compound sieve plates play any role in HLB tolerance or resistance. 

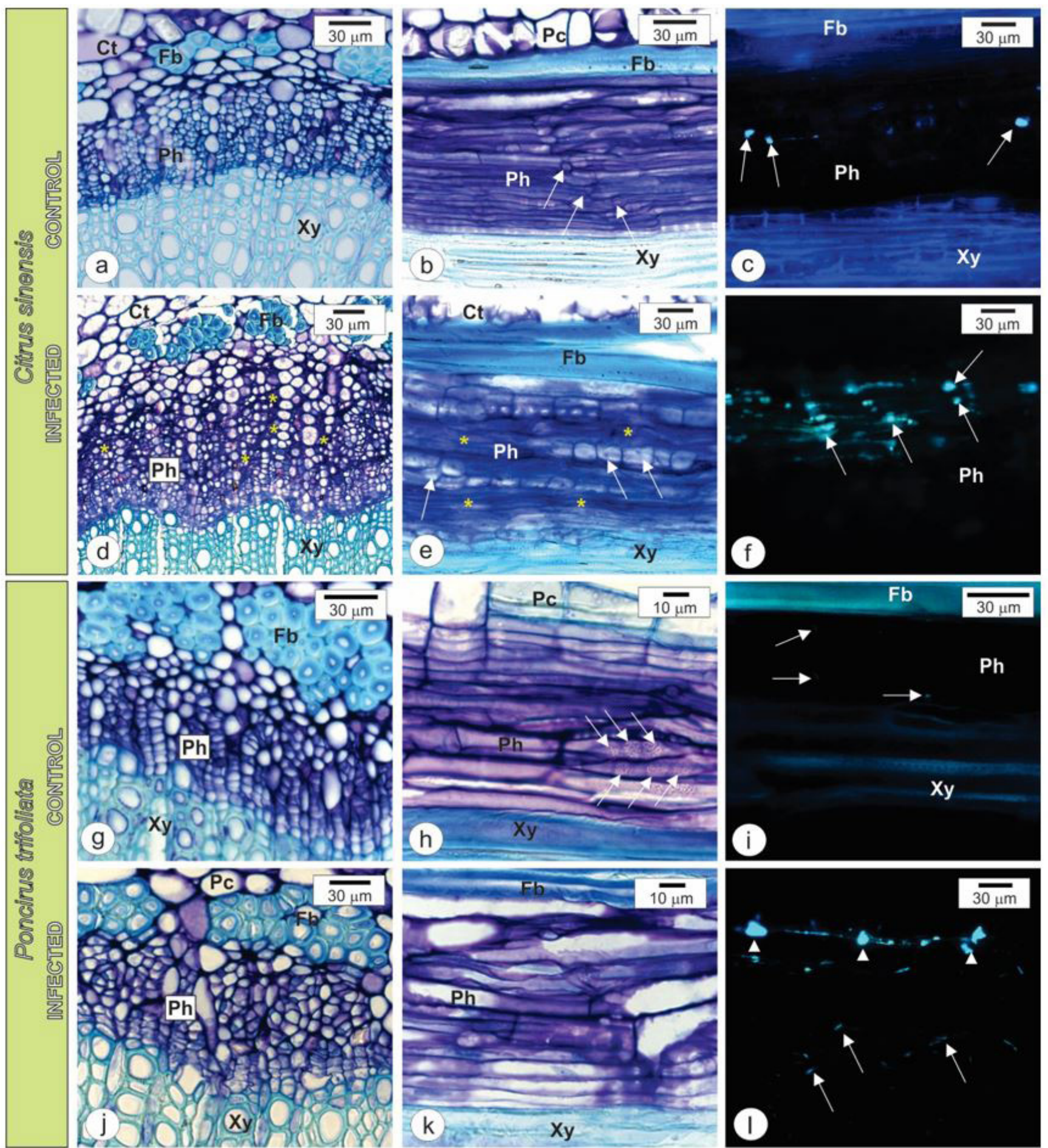

Figure 3. Phloem anatomy of control and CLas infected petioles of Citrus sinensis and Poncirus trifoliata. Cross sections ( $\mathrm{a}, \mathrm{d}, \mathrm{g}, \mathrm{h})$; longitudinal sections (b-c, e-f, h-i, k-l); light microscopy (a-b, d-e, g-h and j-k); fluorescence microscopy after aniline blue staining method $(\mathrm{c}, \mathrm{f}, 1,1)$. In control was observed that $C$. sinensis present a simple sieve plate (arrows in b) and $P$. trifoliata exhibits compound sieve plates (arrows in h). C. sinensis infected plants show collapsed sieve tube elements (* in d-e). Hypertrophy of phloem parenchyma cells (arrows in e). Note the absence of collapsed cells in P. trifoliata (j-k). Callose deposition (arrows in c, f, I, l) occurs in all treatments but more evident in C. sinensis CLas infected. Note that $P$. trifoliata shows large amount of callose deposition associated to a single sieve tube (arrowhead in 1). $\mathrm{Ct}-\mathrm{Cortex}$; Fb - Fiber; Ph - Phloem; Xy - Xylem. 
In our study, callose deposition was observed in CLas infected $P$. trifoliata petiole (Figure 3g-h, 3j-k), albeit with lesser extent to that observed in C. sinensis (Figure 31). There was also weak callose deposition observed in healthy $P$. trifoliata petiole, corroborating previous report (Boava et al., 2017). One important issue observed in $P$. trifoliata is that callose deposition is concentrated to few phloem tubes (Figure 31). Nevertheless, if this difference contributes to the contrasting phenotype observed in the two rutaceous plants remain to be proven, but anatomical structure needs to be considered. Fan et al. (2012) compared the anatomical and transcriptional profile of one tolerant citrus species (rough lemon) with a susceptible one (sweet orange) infected by CLas and noticed callose accumulation and phloem collapse in both genotypes. Callose is a ubiquitous polysaccharide required for several developmental processes in higher plants (Chen \& Kim, 2009). In addition, callose accumulation has been associated to immune-driven defense response against pathogen infection preventing host colonization (Boava et al., 2017; Luna et al., 2011).

Several studies have brought up some divergent aspects regarding callose-mediated defenses (Bonnemain et al., 2013; Ellinger et al., 2013). Arabidopsis mutants for an important callose biosynthesis associated gene pmr4 (POWDERY MILDEW RESISTANT4) show hyperactivation of SA pathway, suggesting a negative regulatory action of callose in SA-mediated signal transduction (Eggert et al., 2014; Nishimura, 2008). In contrast, some researchers suggest that callose genes may be induced by SA (Dong et al., 2008).

Despite the recent progresses toward understanding the citrus - $C a$. Liberibacter pathosystem, there is no conclusive model to explain the evolution of the HLB disease, especially regarding the pathogen-triggered events. Even though $\mathrm{Ca}$. Liberibacter spp. are biotrophic pathogens, the systemic defense response mediated by salicylic acid seems to be inactive, or even compromised. Previous studies have indicated a SA-degrading enzyme coded by a gene present in CLas genome (Wang \& Trivedi, 2013). Furthermore, Xu et al. (2015) reported a depression in SA pathway in CLas infected mandarin (C. reticulata Blanco cv. jiaogan). Our study corroborates those and suggests that possibly $\mathrm{Ca}$. Liberibacter manipulate the plant defense response, converting SA to MeSA in order to suppress the defenses against it and to attract $D$. citri. Additionally, we detected the presence of callose deposition in the phloem of the susceptible $C$. sinensis upon CLas inoculation. However, less callose deposition was found in the tolerant/ resistant genotype $P$. trifoliata Collapsed STE was observed only in sweet orange plants, suggesting that the occlusion of sieve elements could have a prominent implication to the impairment of phloem transport in susceptible citrus plants, what can at least partially explain the HLB symptoms. Another important factor observed here and that could be associated with P. trifoliata tolerance/ resistance to HLB is the anatomic differences of the sieve plates. Here, we suggest that the compound sieve plate could have a role in keeping the phloem function in infected plants.

\section{ACKNOWLEDGEMENTS}

The authors would like to thank Dr. Michèle Breton, Dr. Valeria Mafra, Dr. Eliane Locali and Ms. Carolina Sardinha Francisco for their assistance in carrying out the experiments. The authors also thank Prof. Dr. Beatriz Appezzato da Glória for allowing microscopical analysis at Laboratório de Anatomia Vegetal (LanVeg), ESALQ/USP. This study was supported by the INCT-Citrus/FAPESP/CNPq and Embrapa-Monsanto agreement. Oliveira, T.S. and Marques, J.P.R. received FAPESP scholarships (2011/16518-3 and 2009/00425-6, respectively). Granato, L.M is currently a postdoctoral fellow (FAPESP 2019/01901-8).

\section{REFERENCES}

Achor, D. S., Etxeberria, E., Wang, S. Y., Folimonova, K. R., Albrigo, C., \& Albrigo, L. G. (2010). Sequence of anatomical symptom observations in citrus affected with huanglongbing disease. Plant Pathology Journal, 9(2), 56-64.

Ádám, A. L., Nagy, Z., Kátay, G., Mergenthaler, E., \& Viczián, O. (2018). Signals of systemic immunity in plants: progress and open questions. International Journal of Molecular Sciences, 19(4), 1-21.

Aritua, V., Achor, D., Gmitter, F. G., Albrigo, G., \& Wang, N. (2013). Transcriptional and microscopic analyses of citrus stem and root responses to Candidatus Liberibacter asiaticus Infection. PLoS One, 8(9), 4-8.

Attaran, E., Zeier, T. E., Griebel, T., \& Zeier, J. (2009). Methyl salicylate production and jasmonate signaling are not essential for systemic acquired resistance in Arabidopsis. The Plant Cell Online, 21(3), 954-971. 
Bassanezi, R. B., Montesino, L. H., Gasparoto, M. C. G., Bergamin Filho, A., \& Amorim, L. (2011). Yield loss caused by huanglongbing in different sweet orange cultivars in São Paulo, Brazil. European Journal of Plant Pathology, 130(4), 577-586.

Berardini, T. Z., Reiser, L., Li, D., Mezheritsky, Y., Muller, R., Strait, E., \& Huala, E. (2015). The Arabidopsis information resource: making and mining the "gold standard" annotated reference plant genome. Genesis, 53(8), 474-485. https://doi.org/10.1002/dvg.22877.

Boava, L. P., Cristofani-Yaly, M., \& Machado, M. (2017). Physiologic, anatomic, and gene expression changes in Citrus sunki, Poncirus trifoliata and their hybrids after Liberibacter asiaticus infection. Phytopathology, 107(5), 590-599.

Bonnemain, J. L., Chollet, J. F., \& Rocher, F. (2013) Transport of salicylic acid and related compounds. In $\mathrm{S}$. Hayat \& A. Ahmad (Eds.), Salicilic acid. USA: Springer.

Bové, J. M. (2006). Huanglongbing: a destructive, newlyemerging, century-old disease of citrus. Journal of Plant Pathology, 88(1), 7-37.

Chen, F., D’Auria, J. C., Tholl, D., Ross, J. R., Gershenzon, J., Noel, J. P., \& Pichersky, E. (2003). An Arabidopsis thaliana gene for methylsalicylate biosynthesis, identified by a biochemical genomics approach, has a role in defense. The Plant Journal, 36(5), 577-588.

Chen, X. Y., \& Kim, J. Y. (2009). Callose synthesis in higher plants. Plant Signaling \& Behavior, 4(6), 489-492.

Chen, Z., Zheng, Z., Huang, J., Lai, Z., \& Fan, B. (2009). Biosynthesis of salicylic acid in plants. Plant Signaling \& Behavior, 4(6), 493-496.

Coletta-Filho, H. D., Targon, M. L. P. N., Takita, M. A., De Negri, J. D., Pompeu Junior, J., Machado, M. A., Amaral, A. M., \& Muller, G. W. (2004). First report of the causal agent of huanglongbing ("Candidatus Liberibacter asiaticus ") in Brazil. Plant Disease, 88(12)

Cui, H., Gobbato, E., Kracher, B., Qiu, J., Bautor, J., \& Parker, J. E. (2017). A core function of EDS1 with PAD4 is to protect the salicylic acid defense sector in Arabidopsis immunity. New Phytopathology., 213, 1802-1817.

Cui, J., Bahrami, A. K., Pringle, E. G., Hernandez-Guzman, G., Bender, C. L., Pierce, N. E., \& Ausubel, F. M. (2005). Pseudomonas syringae manipulates systemic plant defenses against pathogens and herbivores. Proceedings of the National Academy of Sciences of the United States of America, 102(5), 1791-1796.

Dempsey, D. M. A., \& Klessig, D. F. (2017). How does the multifaceted plant hormone salicylic acid combat disease in plants and are similar mechanisms utilized in humans? BMC Biology, 15(23), 1-12.

Dong, X., Hong, Z., Chatterjee, J., Kim, S., \& Verma, D. P. S. (2008). Expression of callose synthase genes and its connection with Npr1 signaling pathway during pathogen infection. Planta, 229(1), 87-98.

Eggert, D., Naumann, M., Reimer, R., \& Voigt, C. A. (2014). Nanoscale glucan polymer network causes pathogen resistance. Scientific Reports, 4, 1-6.

Ellinger, D., \& Voigt, C. A. (2014). Callose biosynthesis in arabidopsis with a focus on pathogen response: What we have learned within the last decade. Annals of Botany, 114(6), 1349-1358.

Ellinger, D., Naumann, M., Falter, C., Zwikowics, C., Jamrow, T., Manisseri, C., Somerville, S. C., \& Voigt, C. A. (2013). Elevated early callose deposition results in complete penetration resistance to powdery mildew in arabidopsis. Plant Physiology, 161(3), 1433-1444.

Etxeberria, E., Gonzalez, P., Achor, D., \& Albrigo, G. (2009). Anatomical distribution of abnormally high levels of starch in HLB-affected Valencia orange trees. Physiological and Molecular Plant Pathology, 74(1), 76-83.

Fan, J., Chen, C., Yu, Q., Brlansky, R. H., Li, Z. G., \& Gmitter, F. G. (2011). Comparative iTRAQ proteome and transcriptome analyses of sweet orange infected by "Candidatus Liberibacter asiaticus.". Physiologia Plantarum, 143(3), 235-245.

Fan, J., Chen, C., Yu, Q., Khalaf, A., Achor, D. S., Brlansky, R. H., Moore, G. A., Li, Z. G., \& Gmitter Junior, F. G. (2012). Comparative transcriptional and anatomical analyses of tolerant rough lemon and susceptible sweet orange in response to 'Candidatus Liberibacter asiaticus' infection. Molecular Plant-Microbe Interactions, 25(11), 1396-1407.

Folimonova, S. Y., Robertson, C. J., Garnsey, S. M., Gowda, S., \& Dawson, W. O. (2009). Examination of the responses of different genotypes of citrus to huanglongbing (citrus greening) under different conditions. Phytopathology, 99(12), 1346-1354.

Goodstein, D. M., Shu, S., Howson, R., Neupane, R., Hayes, R. D., Fazo, J., Mitros, T., Dirks, W., Hellsten, 
U., Putnam N., \& Rokhsar, D. S. (2012). Phytozome: a comparative platform for green plant genomics. Nucleic Acids Research, 40(D1), D1178-D1186. https://doi. org/10.1093/nar/gkr944.

Gottwald, T. R. (2010). Current epidemiological understanding of citrus huanglongbing. Annual Review of Phytopathology, 48, 119-139.

Grafton-Cardwell, E. E., Stelinski, L. L., \& Stansly, P. A. (2013). Biology and management of asian citrus psyllid, vector of the huanglongbing pathogens. Annual Review of Entomology, 58, 413-432.

Graça, J. V., Douhan, G. W., Halbert, S. E., Keremane, M. L., Lee, R. F., Vidalakis, G., \& Zhao, H. (2016). Huanglongbing: an overview of a complex pathosystem ravaging the world's citrus. Journal of Integrative Plant Biology, 58(4), 373-387.

Johnson, E. G., Wu, J., Bright, D. B., \& Graham, J. H. (2014). Association of "Candidatus Liberibacter asiaticus" root infection, but not phloem plugging with root loss on huanglongbing-affected trees prior to appearance of foliar symptoms. Plant Pathology, 63(2), 290-298.

Karnovsky, M. J. (1965). A formaldehyde-glutaraldehyde fixative of righ osmolality for use in electron microscopy. The Journal of Cell Biology, 27(15), 137.

Kawano, T., \& Bouteau, F. (2013) Salicylic acid-indiced local and long-distance signaling models in plants. In F. Baluska (Ed.), Long-distance systemic signaling and communication in plants. Berlin: Springer-Verlag. 412p.

Knepper, C., Savory, E. A., \& Day, B. (2011). Arabidopsis NDR1 is an integrin-like protein with a role in fluid loss and plasma membrane-cell wall adhesion. Plant Physiology, 156(1), 286-300.

Koh, E. J., Zhou, L., Williams, D. S., Park, J., Ding, N., Duan, Y. P., \& Kang, B. H. (2012). Callose deposition in the phloem plasmodesmata and inhibition of phloem transport in citrus leaves infected with "Candidatus Liberibacter asiaticus.”. Protoplasma, 249(3), 687-697.

Koo, Y. J., Kim, M. A., Kim, E. H., Song, J. T., Jung, C., Moon, J. K., Kim, J. H., Seo, H. S., Song, S. I., Kim, J. K., Lee, J. S., Cheong, J. J., Choi, Y. D. (2007). Overexpression of salicylic acid carboxyl methyltransferase reduces salicylic acid-mediated pathogen resistance in Arabidopsis thaliana. Plant Molecular Biology, 64, 1-15.

Li, J., Pang, Z., Trivedi, P., Zhou, X., Ying, X., Jia, H., \& Wang, N. (2017). 'Candidatus Liberibacter asiaticus' encodes a functional salicylic acid (SA) hydroxylase that degrades SA to suppress plant defenses. Molecular Plant-Microbe Interactions, 30, 620-630.

Liu, P. P., Yang, Y., Pichersky, E., \& Klessig, D. F. (2010). Altering expression of benzoic acid/salicylic acid carboxyl methyltransferase 1 compromises systemic acquired resistance and PAMP-triggered immunity in Arabidopsis. Molecular Plant-Microbe Interactions, 23(1), 82-90.

Lu, H., Zhang, C., Albrecht, U., Shimizu, R., Wang, G., \& Bowman, K. D. (2013). Overexpression of a citrus NDR1 ortholog increases disease resistance in Arabidopsis. Frontiers of Plant Science, 4, 1-10.

Luna, E., Pastor, V., Robert, J., Flors, V., Mauch-Mani, B., \& Ton, J. (2011). Callose deposition: a multifaceted plant defense response. Molecular Plant-Microbe Interactions, 24(2), 183-193.

Mafra, V., Kubo, K. S., Alves-Ferreira, M., RibeiroAlves, M., Stuart, R. M., Boava, L. P., Munari, C. M., \& Machado, M. A. (2012). Reference genes for accurate transcript normalization in citrus genotypes under different experimental conditions. PLoS One, 7(2), e31263-e31263.

Mafra, V., Martins, P. K., Francisco, C. S., RibeiroAlves, M., Freitas-Astúa, J., \& Machado, M. A. (2013). Candidatus Liberibacter americanus induces significant reprogramming of the transcriptome of the susceptible citrus genotype. BMC Genomics, 14(1), 247.

Mann, R. S., Ali, J. G., Hermann, S. L., Tiwari, S., PelzStelinski, K. S., Alborn, H. T., \& Stelinski, L. L. (2012). Induced release of a plant-defense volatile "deceptively" attracts insect vectors to plants infected with a bacterial pathogen. PLoS Pathogens, 8(3), e1002610-e1002610.

Maruri-López, I., Aviles-Baltazar, N. Y., Buchala, A., \& Serrano, M. (2019). Intra and extracellular journey of the phytohormone salicylic acid. Frontiers of Plant Science, 10(423), 1-11.

Nishimura MT (2008). Loss of a callose synthase results in salicylic acid - dependent. Science, 969(2003), 969-972.

Nwugo, C. C., Duan, Y., \& Lin, H. (2013). Study on citrus response to huanglongbing highlights a down-regulation of defense-related proteins in lemon plants upon "Ca. Liberibacter asiaticus" infection. PLoS One, 8(6), 1-13.

Pitino, M., Armstrong, C. M., \& Duan, Y. (2017). Molecular mechanisms behind the accumulation of ATP and $\mathrm{H} 2 \mathrm{O} 2$ in citrus plants in response to "Candidatus Liberibacter asiaticus" infection. Horticulture Research, 4, 1-8. 
Pitino, M., Armstrong, C. M., Cano, L. M., \& Duan, Y. (2016). Transient expression of Candidatus liberibacter asiaticus effector induces cell death in Nicotiana benthamiana. Frontiers of Plant Science, 7, 1-13.

Qi, G., Chen, J., Chang, M., Chen, H., Hall, K., Korin, J., Liu, F., Wang, D., \& Fu, Z. Q. (2018). Pandemonium Breaks Out: Disruption of Salicylic Acid-Mediated Defense by Plant Pathogens. Molecular Plant, 11, 1-13.

Rawat, N., Kiran, S. P., Du, D., Gmitter, F. G., \& Deng, Z. (2015). Comprehensive meta-analysis, co-expression, and miRNA nested network analysis identifies gene candidates in Citrus against Huanglongbing disease. BMC Plant Biology, 15, 184.

Rietz, S., Stamm, A., Malonek, S., Wagner, S., Becker, D., Medina-Escobar, N., Vlot, A. C., Feys, B. J., Niefind, K., \& Parker, J. E. (2011). Different roles of Enhanced Disease Susceptibility1 (EDS1) bound to and dissociated from Phytoalexin Deficient4 (PAD4) in Arabidopsis immunity. The New Phytologist, 191(1), 107-119.

Sakai, W. S. (1973). simple method for differential staining of paraffin embedded plant material using toluidine blue. Stain Technology, 48(5), 247-249.

Shah, J., \& Zeier, J. (2013). Long-distance communication and signal amplification in systemic acquired resistance. Frontiers of Plant Science, 4, 1-16.

Slisz, A. M., Breksa, A. P., Mishchuk, D. O., McCollum, G., \& Slupsky, C. M. (2012). Metabolomic analysis of citrus infection by "Candidatus Liberibacter" reveals insight into pathogenicity. Journal of Proteome Research, 11(8), 4223-4230.

Spoel, S. H., Mou, Z., Tada, Y., Spivey, N. W., Genschik, P., \& Dong, X. (2009). Proteasome-mediated turnover of the transcription coactivator NPR1 plays dual roles in regulating plant immunity. Cell, 137(5), 860-872.

Tanaka, S., Han, X., \& Kahmann, R. (2015). Microbial effectors target multiple steps in the salicylic acid production and signaling pathway. Frontiers of Plant Science, 6, 1-10.

Teixeira, D. D. C., Saillard, C., Eveillard, S., Danet, J. L., da Costa, P. I., Ayres, A. J., \& Bové, J. (2005). "Candidatus Liberibacter americanus", associated with citrus huanglongbing (greening disease) in São Paulo State, Brazil. International Journal of Systematic and Evolutionary Microbiology, 55, 1857-1862.

Untergasser A., Nijveen H., Rao X., Bisseling T., Geurts R., \& Leunissen, J. A. M. (2007). Primer3Plus, an enhanced web interface to Primer3. Nucleic Acids Research, 35 (Suppl 2), W71-W74. https://doi.org/10.1093/nar/gkm306.

Vilaine, F., Kerchev, P., Clément, G., Batailler, B., Cayla, T., Bill, L., Gissot, L., \& Dinant, S. (2013). Increased Expression of a phloem membrane protein encoded by NHL26 alters phloem export and sugar partitioning in Arabidopsis. The Plant Cell, 25(5), 1689-1708.

Wang, N., \& Trivedi, P. (2013). Citrus huanglongbing: a newly relevant disease presents unprecedented challenges. Phytopathology, 103(7), 652-665.

Wang, N., Pierson, E. A., Setubal, C., Xu, J., Levy, J. G., Zhang, Y., Li, J., Rangel, L. T., \& Martins Jr, J. (2017). The candidatus liberibacter-host interface: insights into pathogenesis mechanisms and disease control. Annual Review of Phytopathology, 55, 1-32.

Wildermuth, M. C., Dewdney, J., Wu, G., \& Ausubel, F. M. (2001). Isochorismate synthase is required to synthesize salicylic acid for plant defence. Nature, 414, 562-571.

Wu, Y., Zhang, D., Chu, J. Y., Boyle, P., Wang, Y., Brindle, I. D., De Luca, V., \& Després, C. (2012). The Arabidopsis NPR1 protein is a receptor for the plant defense hormone salicylic acid. Cell Reports, 1(6), 639-647.

Xing, F., Li, Z., Sun, A., \& Xing, D. (2013). Reactive oxygen species promote chloroplast dysfunction and salicylic acid accumulation in fumonisin B1-induced cell death. FEBS Letters, 587(14), 2164-2172.

Xu, M., Li, Y., Zheng, Z., Dai, Z., Tao, Y., \& Deng, X. (2015). Transcriptional analyses of mandarins seriously infected by "Candidatus liberibacter asiaticus". PLoS One, 10(7), 1-18.

Zhao, S., \& Fernald, R. D. (2005). Comprehensive algorithm for quantitative real-time polymerase chain reaction. Journal of Computational Biology, 12(8), 1047-1064.

Zheng, X., Spivey, N. W., Zeng, W., Liu, P., Fu, Z. Q., Klessig, D. F., He, S. Y., \& Dong, X. (2012). Coronatine promotes Pseudomonas syringae virulence in plants by activating a signaling cascade that inhibits salicylic acid accumulation. Cell Host \& Microbe, 11(6), 587-596.

Received: April 24, 2019

Accepted: August 19, 2019

How to cite: Oliveira, T. S., Granato, L. M., Galdeano, D. M., Marques, J. P. R., Coerini, L. F., Freitas-Astúa, J., \& Machado, M. A. (2019). Genetic analysis of salicylic acid-mediated defenses and histopathology in the huanglongbing pathosystem. Citrus Research \& Technology, 40, e1049. https://doi.org/10.4322/ crt.18419 